\title{
Rancang Bangun Aplikasi Rekapitulasi Obat dengan Menerapkan Tanda Tangan Digital
}

\author{
Aulia Tri Rahmawati ${ }^{1}$, Raden Budiarto Hadiprakoso ${ }^{2}$ \\ ${ }^{1,2}$ Rekayasa Kriptografi, Poltek Siber dan Sandi Negara, Bogor, Indonesia \\ 2 raden.budiarto@poltekssn.ac.id
}

Diterima 09 September 2020

Disetujui 18 November 2020

\begin{abstract}
The current condition experienced by the XYZ Polyclinic is that there is no application built to simplify the service process contained in the polyclinic so that all service processes are still manual. An example is the calculation of the number of drugs that are in and out of use. This calculation takes a long time, is prone to errors in accounting, and consumes many papers. To solve this problem, we develop an application to recap drugs. The drug recapitulation application is based on a website with the WebML method using the CodeIgniter framework and MySQL database. The application produces the result in the form of a PDF file of the drug recapitulation report per month and day. As a security feature, the monthly drug recapitulation report results include a digital signature as proof of authentication, integrity, and anti-denial. The application built has been tested using web testing methods and user acceptance testing to be applied.
\end{abstract}

Index Terms - cryptography, digital signature, drug recapitulation, WebML

\section{Pendahuluan}

Poliklinik merupakan gabungan dari beberapa klinik yang menyelenggarakan pelayanan dasar medis baik umum maupun khusus sesuai dengan peraturan menteri kesehatan nomor 9 tahun 2014 [1]. Kondisi yang dialami oleh poliklinik XYZ saat ini adalah belum adanya sistem informasi yang dibangun untuk mempermudah proses pelayanan pada poliklinik sehingga segala proses pelayanan masih secara manual. Salah satunya ketika perhitungan jumlah obat yang masuk maupun yang habis. Hal ini menyebabkan proses pelayanan menjadi lama karena membutuhkan waktu dalam perhitungan, kesalahan dalam perhitungan jumlah obat, pemborosan kertas dalam proses pencatatan jumlah obat, dan kertas formulir rekapitulasi obat yang tersimpan secara bertumpuk dengan jumlah berkisar 290 lembar per bulan.

Melihat kondisi tersebut, maka diperlukan sebuah aplikasi yang dapat mengatasi permasalahan proses rekapitulasi obat poliklinik XYZ. Hal tersebut sejalan dengan peraturan menteri kesehatan Republik Indonesia nomor 46 tahun 2017 yang mendukung penerapan teknologi informasi dan komunikasi (TIK) pada layanan kesehatan [2]. Penerapan TIK di bidang Kesehatan telah menjadi tuntutan organisasi atau institusi kesehatan tidak saja di sektor pemerintah tetapi juga di sektor swasta dalam rangka menjalankan operasional pelayanannya agar lebih efisien.

Mengingat aplikasi di bidang layanan kesehatan berperan sangat vital bagi kebutuhan manusia maka faktor keamanan dari aplikasi sangat diperlukan. Ketika resep obat keluar harus dapat dipastikan resep tersebut benar-benar diotorisasi dokter yang berwenang. Berdasarkan hasil permasalahan di atas, maka akan dibangun sebuah aplikasi yang memiliki fitur keamanan yaitu tanda tangan digital. Hal penting karena tanda digital berperan sebagai faktor antipenyangkalan karena hanya dapat diautentikasi oleh pemilik kunci privat [3] yang dalam hal adalah dokter yang bertugas.

Aplikasi ini memiliki dua aktor utama yaitu admin, dan petugas rekap obat. Pada aktor utama admin atau dokter, sistem akan mengelola akun pengguna dan menandatangani laporan pengeluaran obat per bulan sebagai entitas yang mengesahkan laporan rekap obat per bulan dan menjamin layanan keamanan dokumen yang ditandatangani dalam aspek integritas, otentikasi, dan anti-penyangkalan. Sedangkan pada aktor utama petugas rekap obat, sistem akan melakukan perhitungan pengeluaran obat per hari yang dihitung secara otomatis dan laporan pengeluaran obat per bulan yang dapat di cetak ke dalam file PDF dan hanya mencantumkan nama dokter sebagai entitas yang mengesahkan laporan rekap obat per bulan. Dengan keberadaan aplikasi rekapitulasi obat ini diharapkan akan memberikan kemudahan dalam proses rekapitulasi obat.

\section{LANDASAN TEORI}

Secara garis besar digital signature adalah sebuah skema identifikasi matematis yang secara unik seorang pengirim. Hal ini biasanya digunakan untuk membuktikan keaslian dari pemilik sebuah pesan atau dokumen digital. Sebuah digital signature yang autentik (sah), sudah cukup menjadi alasan bagi penerima untuk percaya bahwa sebuah pesan atau dokumen yang diterima adalah berasal dari pengirim yang telah diketahui [4]. Digital Signature menerapkan konsep algoritma sandi, di mana 
algoritma sandi itu sendiri adalah sebuah skema dengan tujuan kriptografi [5].

Teknologi digital signature memanfaatkan teknologi kunci publik. Sepasang kunci publik dan privat dibuat untuk keperluan seseorang. Kunci privat ada pada pemiliknya untuk membuat tanda tangan digital. Kunci publik dapat diserahkan kepada siapa saja yang ingin memeriksa tanda tangan digital pada suatu dokumen [6]. Proses pembuatan dan pemeriksaan tanda tangan menggunakan teknik kriptografi seperti hashing dan enkripsi asimetris. Gambar 1 merupakan bagan cara penggunaan digital signature.

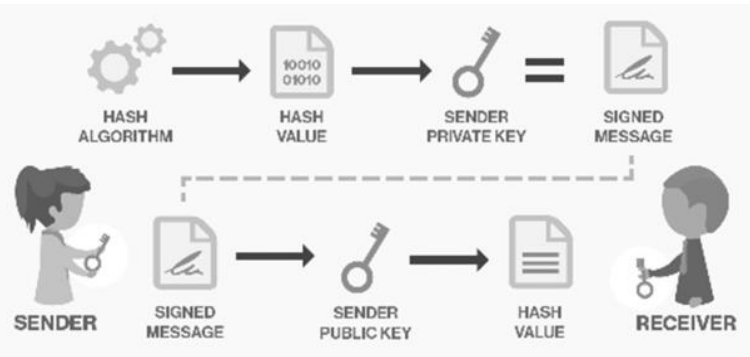

Gambar 1. Alur penggunaan digital signature [7]

WebML merupakan metodologi perancangan web generasi ketiga yang digagas pada tahun 1998 oleh para pionir yang bekerja di dalam bidang hypermedia dan desain web [8]. Tujuan dari dikembangkannya WebML adalah untuk membantu merancang dan mengimplementasikan. data-intensive Web application yang didefinisikan sebagai situs web untuk mengakses dan memelihara sejumlah besar data terstruktur yang pada umunya disimpan dalam sebuah Database Management System (DBMS) seperti situs penjualan online atau e-commerce, website kelembagaan baik swasta ataupun publik, perpustakaan digital, situs komunitas dan sebagainya. WebML adalah sebuah bahasa visual untuk menentukan struktur dari sebuah aplikasi web termasuk di dalamnya proses organisasi dan penyajian konten web tersebut ke dalam format hypertext [9]. Gambar 2 adalah fase dalam pengembangan aplikasi web dengan menggunakan WebML.

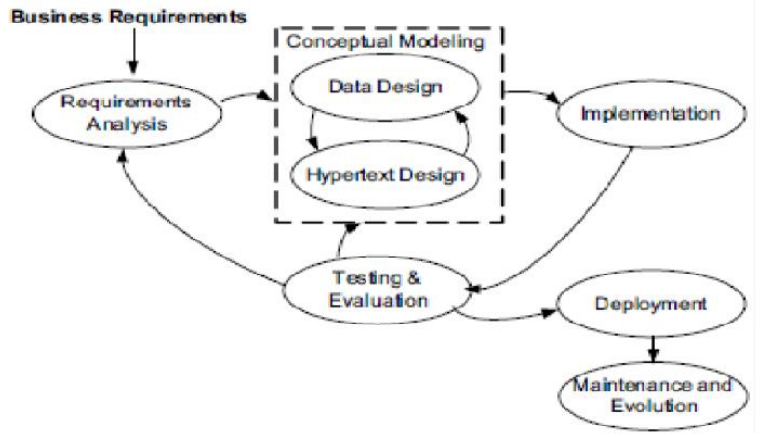

III. MetodoloGI

Pada penelitian ini metodologi penelitian yang digunakan adalah penelitian kualitatif dengan metode pengembangan perangkat lunak Web Modelling Language (WebML). Penelitian kualitatif adalah penelitian yang bersifat deskriptif dan cenderung menggunakan analisis. Langkah-langkah dalam WebML yaitu, requirement analysis, conceptual modelling, implementation, testing and evaluation, deployment dan maintenance \& evolution. namun dalam penelitian ini diberikan batasan langkah hanya sampai dengan testing and evaluation.

\section{A. Analisis Kebutuhan}

Pada tahap ini peneliti melakukan analisis dari hasil wawancara dan studi literatur yang telah dilakukan. Output dari tahap ini adalah kebutuhan fungsional dan non-fungsional. Berikut adalah analisis kebutuhan sistem yang dibangun:

1. Aplikasi memiliki fungsi login dan daftar untuk admin dan petugas rekap obat.

2. Aplikasi memiliki fungsi cetak laporan obat per bulan dan per hari dengan mencantumkan tanda tangan digital.

3. Aplikasi memiliki fungsi lihat, tambah, edit $\&$ hapus nama obat.

4. Aplikasi memiliki fungsi lihat, tambah, edit \& hapus kategori obat.

5. Aplikasi memiliki fungsi terima obat.

6. Aplikasi memiliki fungsi obat keluar.

7. Aplikasi memiliki fungsi obat terpakai.

8. Aplikasi memiliki fungsi update stok obat secara otomatis.

9. Aplikasi berbasis web dan hanya dapat diakses melalaui jaringan lokal.

\section{B. Perancangan Model Konseptual}

Pada tahap ini akan dirancang data design dan hypertext design. Data Design merupakan skema data dari objek informasi inti yang dihasilkan. Sedangkan Hypertext Design merupakan skema tampilan situs di atas skema data yang telah ditentukan sebelumnya. Data Design dari perancangan aplikasi rekapitulasi obat yaitu Entity Relationship Diagram seperti yang ditampilkan pada Gambar 3.

Gambar 2. Alur metodologi WebML [10] 


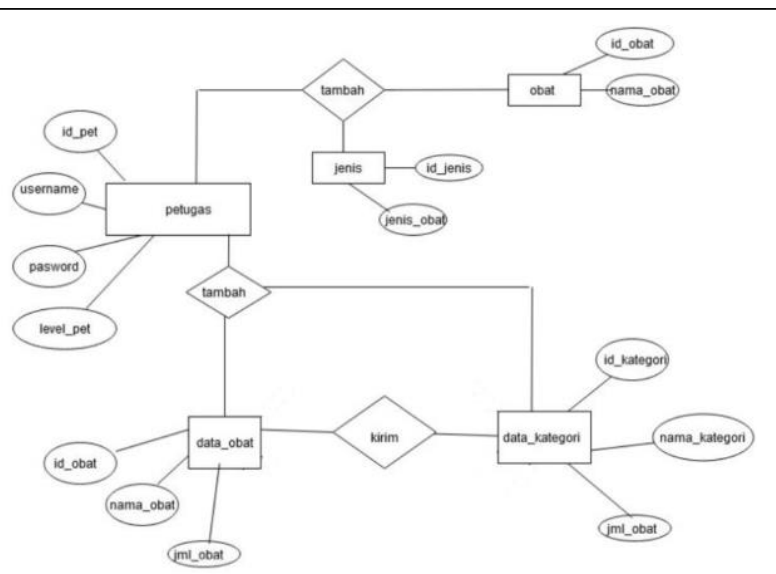

Gambar 3. Entity relationship diagram

Hypertext Design menggambarkan tampilan dari aplikasi rekapitulasi obat yang menjelaskan secara detail link antar halaman dan isi dari konten unit. Hypertext Design terdiri dari Site View dan Hypertext Diagram. Site View menjelaskan isi dan layanan yang disediakan pada halaman Hypertext Design. Site View terdiri dari dua kelompok bagian halaman yaitu Home page, Default page. Tampilan site view diilustrasikan pada Gambar 4.

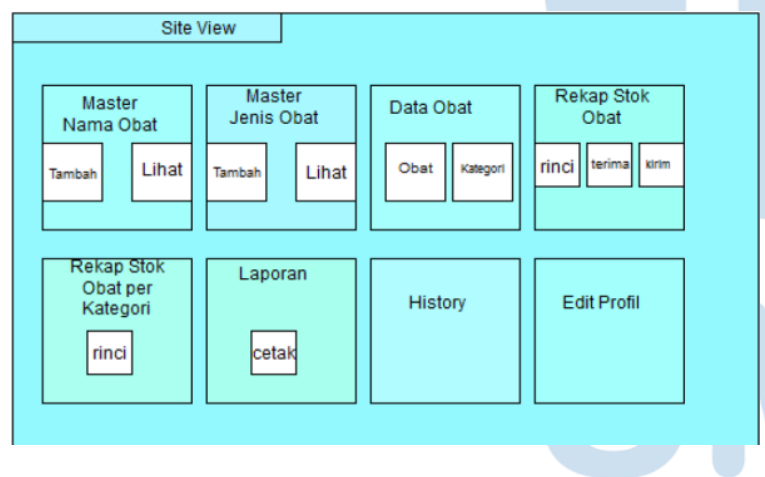

Gambar 4. Tampilan site view

\section{Implementasi}

Pada tahap ini akan dilakukan implementasi aplikasi menggunakan framework codeigniter yang menerapkan konsep Model, View, dan Controller (MVC), bahasa pemrograman PHP, Apache Xampp (server), teks editor sublime Text 3 dan basis data MySQL Berikut merupakan tahap yang akan dilakukan: Membangun aplikasi yang sudah dirancang dengan bahasa pemrograman PHP. Implementasi rancangan antar muka menggunakan HTML dan CSS, implementasi rancangan basis data menggunakan MySQL. Menerapkan fungsi hash sebagai pengamanan password agar tidak mudah diketahui oleh pihak lain dan mencetak bukti laporan per bulan berupa file PDF dengan algoritma RSA untuk tanda tangan elektronik sebagai bukti otentikasi, integritas, dan anti penyangkalan. Adapun gambaran umum aplikasi yang akan dibangun diilustrasikan pada gambar 5.

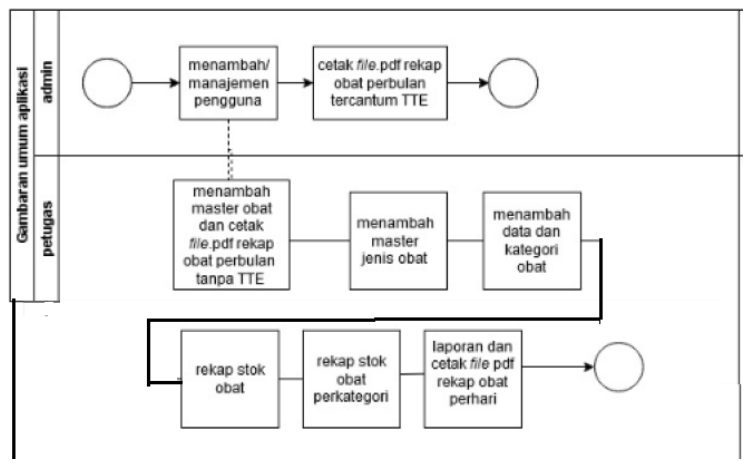

Gambar 5. Gambaran umum aplikasi

\section{Pengujian}

Hasil dari tahap implementasi selanjutnya diuji dengan beberapa pengujian berdasarkan Web Testing dan User Acceptance Testing.

- Functional testing dilakukan dengan menguji semua link yang ada pada aplikasi. Pengujian dilakukan pada dua bagian yaitu button dan link Test, dan Database Test. Setiap uji yang dilakukan berdasarkan test case.

- Compability testing dilakukan dengan menguji aplikasi terhadap jenis browser. Pengujian ini dilakukan dengan layanan browser compability test pada situs www.lamdabdatest.com.

- Performance testing dilakukan untuk mengetahui performa dari aplikasi yang dibuat. Pengujian melalui situs www.gtmetrix.com.

- Security testing dilakukan dengan cara melakukan paste alamat web pada web URL tanpa melakukan login. Seharusnya apabila pengujian berhasil maka halaman internal tidak dapat bisa terbuka apabila tidak melakukan login terlebih dahulu.

- User Acceptance Testing (UAT) dilakukan dengan tujuan untuk mengonfirmasi bahwa sistem dapat diterima dan sesuai kebutuhan pengguna.

\section{HASIL DAN PEMBAHASAN}

Pada tahap ini peneliti menjelaskan hasil implementasi dari aplikasi rekapitulasi obat. Secara keseluruhan aplikasi terdiri dari tiga buah tampilan yang dapat dilihat pada Tabel 1 .

Tabel 1. Data training

\begin{tabular}{|l|l|}
\hline Jenis Tampilan & Dekripsi Tampilan \\
\hline Tampilan Login dan & Merupakan tampilan awal dari aplikasi \\
\hline
\end{tabular}


ISSN 2085-4579

\begin{tabular}{|l|l|}
\hline Logout & $\begin{array}{l}\text { rekapitulasi obat poliklinik yang dapat } \\
\text { diakses oleh seluruh pengguna. }\end{array}$ \\
\hline Tampilan Admin & $\begin{array}{l}\text { Merupakan tampilan aplikasi rekapitulasi } \\
\text { obat poliklinik dengan hak akses login } \\
\text { sebagai pengelola akun seluruh } \\
\text { pengguna dan menandatangani laporan } \\
\text { rekap obat per bulan secara digital. }\end{array}$ \\
\hline Tampilan Petugas & $\begin{array}{l}\text { Merupakan tampilan aplikasi rekapitulasi } \\
\text { obat poliklinik dengan hak akses login } \\
\text { sebagai petugas rekap obat. }\end{array}$ \\
\hline
\end{tabular}

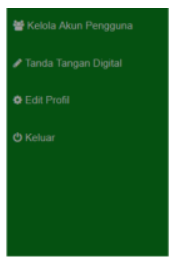

Kelola akun pengguna

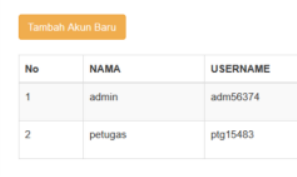

Gambar 6. Halaman kelola akun

Gambar 6 menjelaskan mengenai tampilan awal saat melakukan login sebagai admin. Fitur yang disediakan aktor admin yaitu kelola akun pengguna, menandatangani laporan rekap obat per bulan secara digital, dan edit profil. Pada halaman kelola akun pengguna admin dapat menambahkan akun, mengedit akun, dan menghapus akun.

Untuk menambahkan jenis obat, Petugas rekap obat harus memilih menu master jenis obat maka akan muncul form tambah jenis obat dan memasukkan satu inputan yaitu jenis obat. Inputan pada form tambah jenis obat akan tersimpan secara otomatis pada database dan muncul pada tabel lihat jenis obat. Merupakan halaman cetak laporan rekap obat per bulan dengan tanda tangan digital. Admin atau dokter dapat menandatangani hasil rekapitulasi obat per bulan secara digital. Dokter dapat menandatangani hasil rekapitulasi obat per bulan secara digital. Pada Gambar 7 merupakan tampilan hasil file PDF laporan rekapitulasi obat per bulan yang telah tercantum tanda tangan digital dokter.

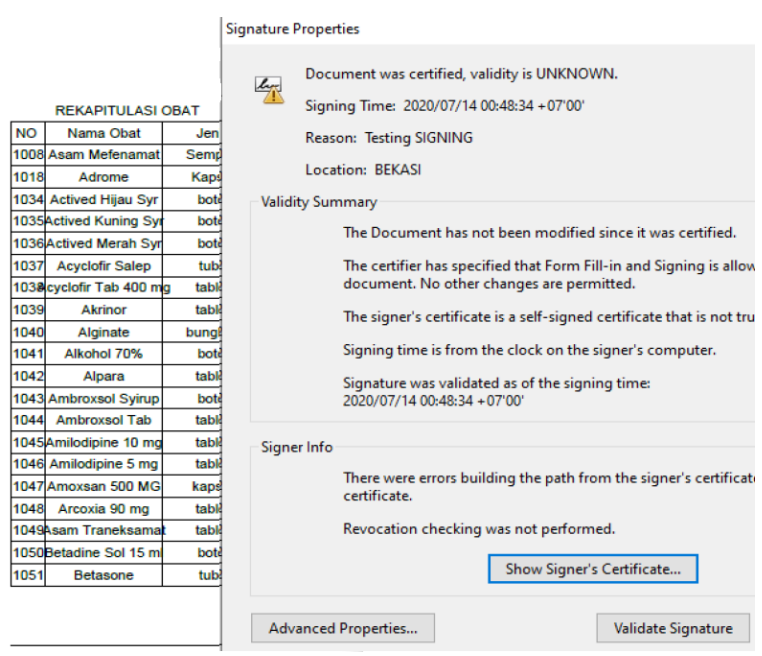

Gambar 7. Digital signature pada rekapitulasi obat

Setelah aplikasi berhasil diimplementasikan, aplikasi akan diuji. Pengujian yang pertama dilakukan adalah pengujian fungsional terhadap link dan tombol yang tersedia pada aplikasi. Hasil pengujian fungsional ditampilkan pada Tabel 2.

Tabel 2. Hasil pengujian fungsional

\begin{tabular}{|l|l|l|l|}
\hline $\begin{array}{l}\text { Tombol / } \\
\text { Link }\end{array}$ & Skenario & $\begin{array}{l}\text { Hasil yang } \\
\text { diharapkan }\end{array}$ & Hasil \\
\hline $\begin{array}{l}\text { Tambah } \\
\text { nama } \\
\text { obat }\end{array}$ & $\begin{array}{l}\text { Pengguna menekan } \\
\text { tombol tambah nama } \\
\text { obat menuju } \\
\text { halaman }\end{array}$ & $\begin{array}{l}\text { Sistem } \\
\text { menampilkan } \\
\text { halaman }\end{array}$ & $\mathrm{V}$ \\
\hline $\begin{array}{l}\text { Lihat } \\
\text { nama } \\
\text { obat }\end{array}$ & $\begin{array}{l}\text { Pengguna menekan } \\
\text { tombol lihat nama } \\
\text { obat menuju } \\
\text { halaman }\end{array}$ & $\begin{array}{l}\text { Sistem } \\
\text { menampilkan } \\
\text { halaman }\end{array}$ & $\mathrm{V}$ \\
\hline $\begin{array}{l}\text { Tambah } \\
\text { jenis obat }\end{array}$ & $\begin{array}{l}\text { Pengguna menekan } \\
\text { tombol tambah nama } \\
\text { obat menuju } \\
\text { halaman }\end{array}$ & $\begin{array}{l}\text { Sistem } \\
\text { menampilkan } \\
\text { halaman }\end{array}$ & $\mathrm{V}$ \\
\hline $\begin{array}{l}\text { Lihat } \\
\text { jenis obat }\end{array}$ & $\begin{array}{l}\text { Pengguna menekan } \\
\text { tombol lihat jenis } \\
\text { obat menuju } \\
\text { halaman }\end{array}$ & $\begin{array}{l}\text { Sistem } \\
\text { menampilkan } \\
\text { halaman }\end{array}$ & $\mathrm{V}$ \\
\hline Kategori & $\begin{array}{l}\text { Pengguna menekan } \\
\text { tombol kategori } \\
\text { menuju halaman }\end{array}$ & $\begin{array}{l}\text { Sistem } \\
\text { menampilkan } \\
\text { halaman }\end{array}$ & $\mathrm{V}$ \\
\hline $\begin{array}{l}\text { Pengguna menekan } \\
\text { tombol rekap stok } \\
\text { obat menuju } \\
\text { halaman }\end{array}$ & $\begin{array}{l}\text { Sistem } \\
\text { menampilkan } \\
\text { halaman }\end{array}$ & $\mathrm{V}$ \\
\hline stok Oban & & \\
\hline
\end{tabular}

Pengujian selanjutnya adalah compability testing yang digunakan untuk menguji kesesuaian aplikasi yang telah dibangun dengan web browser pada setiap versinya. Pengujian ini dilakukan dengan menggunakan layanan browser compability test pada situs www.lamdabdatest.com. Browser yang diuji di antaranya mozilla firefox dan google chrome. Hasil pengujian dari aplikasi rekapitulasi obat menunjukkan aplikasi compatible di semua versi firefox mulai dari versi 65 ke atas dan semua versi chrome 70 ke atas. 
Pengujian performa dijalankan dengan menggunakan situs www.gtmetrix.com. Pengujian ini bertujuan untuk mengetahui kinerja aplikasi ketika banyak pengguna yang mengakses aplikasi dalam waktu bersamaan. Gambar 8 menunjukkan bahwa nilai dari page speed aplikasi rekapitulasi obat yaitu $96 \%$ dan nilai dari YSlow $90 \%$ hal ini menunjukkan bahwa performa aplikasi rekapitulasi obat tergolong baik. Pada detail laman yang mencakup fully loaded time, total page size, dan request menunjukkan bawa aplikasi rekapitulasi obat memiliki hasil lebih baik dari rata-rata laman website yang dites hal ini ditunjukkan dengan tanda panah hijau.

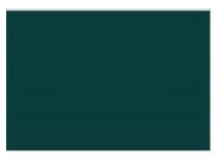

\section{Performance Report for:}

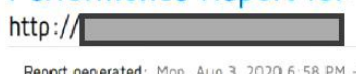

Report generated: Mon, Aug 3, 20206.58 PM -0700 Test Server Region: IN Vancouver, Canada Using: Chrome (Desktop) 75.0.3770.100, Page Speed 1.15-
gt1.3, YSlow 3.1.8

\begin{tabular}{|c|c|c|c|c|}
\hline $\begin{array}{l}\text { PageSpeed Score } \\
\mathbf{A}(96 \%) \wedge\end{array}$ & $\begin{array}{l}\text { Yslow Score } \\
\mathbf{A}(90 \%) \wedge\end{array}$ & $\begin{array}{l}\text { Fully Loaded Time } \\
1.9 \mathrm{~s} \wedge\end{array}$ & $\begin{array}{l}\text { Total Page Size } \\
182 \mathrm{~KB} \wedge\end{array}$ & $\begin{array}{l}\text { Requests } \\
11^{\wedge}\end{array}$ \\
\hline
\end{tabular}

Gambar 8. Hasil performance testing

Pengujian selanjutnya adalah security testing di mana pengujian ini bertujuan untuk mengetahui keamanan dari aplikasi rekapitulasi obat poliklinik. Terdapat beberapa pengujian keamanan sistem informasi web yang dibuat berdasarkan test case. Hasil ringkasan dari pengujian keamanan ditampilkan pada Tabel 3.

Pengujian yang terakhir dilakukan adalah acceptance testing. Pengujian ini bertujuan untuk mengonfirmasi bahwa sistem dapat diterima dan sesuai kebutuhan pengguna. Acceptance testing yang dilakukan yaitu memberikan kuesioner kepada tiga kelompok pengguna yaitu dokter, admin dan perawat. Berdasarkan hasil user acceptance testing aplikasi cukup menjawab permasalahan yang ada yaitu perhitungan obat yang dilakukan secara manual menggunakan perhitungan turus dapat dijawab dengan aplikasi yang melakukan perhitungan secara otomatis dan tidak membutuhkan waktu lama. Selain itu permasalahan mengenai banyaknya kertas berkisar 290 lembar per bulan kertas berukuran A5 yang digunakan untuk laporan rekapitulasi obat per bulan telah teratasi oleh aplikasi yang dapat menghasilkan file PDF sebagai bukti laporan rekapitulasi obat berbentuk digital.

Tabel 3. Ringkasan pengujian keamanan

\begin{tabular}{|l|l|}
\hline Fitur Keamanan & Implementasi pada aplikasi \\
\hline Kerahasiaan & $\begin{array}{l}\text { Pembatasan hak akses pengguna dengan } \\
\text { username dan password yang di hash } \\
\text { menggunakan SHA256. } \\
\text { Penggunaan HTTPS dalam transmisi }\end{array}$ \\
\hline
\end{tabular}

\begin{tabular}{|l|l|}
\hline & lalu lintas data sehingga data terenkripsi. \\
\hline Otentikasi & $\begin{array}{l}\text { Jaminan otentikasi file PDF dengan } \\
\text { algoritma RSA pada tanda tangan } \\
\text { digital. } \\
\text { Setiap form telah disanitasi dan } \\
\text { divalidasi sehingga aman dari injeksi } \\
\text { SQL / kode program. }\end{array}$ \\
\hline Integritas & $\begin{array}{l}\text { Penerapan tanda tangan digital pada file } \\
\text { PDF laporan rekapitulasi obat per bulan. }\end{array}$ \\
\hline Anti & $\begin{array}{l}\text { Tanda tangan digital berupa kunci privat } \\
\text { dan kunci publik / sertifikat yang } \\
\text { digunakan untuk memvalidasi file yang } \\
\text { dikirimkan apabila tanda tangan tersebut } \\
\text { palsu, maka pengguna tersebut tidak } \\
\text { dapat menyangkalnya. }\end{array}$ \\
\hline
\end{tabular}

Pengujian yang terakhir dilakukan adalah acceptance testing. Pengujian ini bertujuan untuk mengonfirmasi bahwa sistem dapat diterima dan sesuai kebutuhan pengguna. Acceptance testing yang dilakukan yaitu memberikan kuesioner kepada tiga kelompok pengguna yaitu dokter, admin dan perawat. Berdasarkan hasil user acceptance testing aplikasi cukup menjawab permasalahan yang ada yaitu perhitungan obat yang dilakukan secara manual menggunakan perhitungan turus dapat dijawab dengan aplikasi yang melakukan perhitungan secara otomatis dan tidak membutuhkan waktu lama. Selain itu permasalahan mengenai banyaknya kertas berkisar 290 lembar per bulan kertas berukuran A5 yang digunakan untuk laporan rekapitulasi obat per bulan telah teratasi oleh aplikasi yang dapat menghasilkan file PDF sebagai bukti laporan rekapitulasi obat berbentuk digital.

\section{SIMPULAN}

Setelah melalui proses pengujian aplikasi maka diperoleh kesimpulan sebagai berikut:

1. Aplikasi rekapitulasi obat Poliklinik XYZ berhasil diimplementasikan menggunakan metode WebML berbasis website yang menghasilkan output laporan per bulan file PDF dengan mencantumkan tanda tangan digital dokter.

2. Aplikasi rekapitulasi obat dapat memenuhi solusi permasalahan yang ada dengan perhitungan obat secara otomatis serta output laporan rekapitulasi obat file PDF dengan jaminan kerahasiaan.

3. Berdasarkan UAT, aplikasi rekapitulasi obat sudah memenuhi solusi permasalahan proses rekapitulasi obat terhadap para penggunanya.

\section{DAFTAR PUSTAKA}

[1] Republik Indonesia, "Peraturan menteri kesehatan nomor 9 tahun 2014 tentang fasilitas layanan kesehatan" 2014

[2] Republik Indonesia, "Peraturan menteri kesehatan nomor 6 
tahun 2017 tentang penerapan TIK pada layanan kesehatan", 2017.

[3] Gunawan, N,K. and Hadiprakoso, R,B. " Comparative Study Between the Integration of ITIL and ISO/IEC 27001 with the Integration of COBIT and ISO/IEC 27001, IOP Conference Series: Materials Science and Engineering" 2020.

[4] M. M. Brambilla, "Designing Web Applications With WebML and Webratio," 2018..

[5] A. Rosyanto, "Pembuatan Aplikasi Layanan Kesehatan Berbasis Web di Rumah sakit umum daerah Yogyakarta," 2010.

[6] R. Guntari dan R. Guanwan, "Rancang bangun aplikasi pelayanan kesahatan pada posyandu," Jurnal Algoritma Sekolah Tinggi Teknologi Garut, vol. 13, no. 1, pp. 269-274, 201620.

[7] Pemerintah Republik Indonesia, "Peraturan Presiden Nomor 95 Tahun 2018 Tentang Sistem Pemerintahan Berbasis Elektronik," 2018.

[8] H. Siregar, E. Junaeti and T. Hayatno, "Implementation of Digital Signature Using AES and RSA Algorithms as a Security in Disposition System af Letter," in IOP Conference Series: Materials Science and Engineering, 2017.

[9] NIST "Federal Information Processing Standards Publication 197 Announcing the Advanced Encryption Standard (AES)," 2001.

[10] A. W. Marashdih, Z. F. Zaaba, K. Suwais and N. A. Mohd, "Web Application Security: An Investigation on Static Analysis with other Algorithms to Detect Cross Site Scripting," in The Fifth Information Systems International Conference 2019, 2019. 